\title{
Persoalan Hukum Penyelesaian Hak atas Tanah dan Lingkungan Berdasarkan Perubahan Undang-Undang Minerba
}

\author{
Wahyu Nugroho \\ Fakultas Hukum Universitas Sahid Jakarta, Jakarta, Indonesia \\ Jln. Prof. Dr. Soepomo, SH No. 84 Tebet Jakarta Selatan Indonesia 12870 \\ wahyulaw86@yahoo.com
}

Received: 29 Agustus 2020; Accepted: 17 November 2020; Published: 15 Desember 2020

https://doi.org/10.20885/iustum.vol27.iss3.art7

\begin{abstract}
Law Number 3 of 2020 on Amendments to Law Number 4 of 2009 on Mineral and Coal Mining (Law No.3 of 2020) contains substantial problems. The problems are first, regarding the settlement of land rights for problematic mineral and coal mining business activities, second, regarding the licensing mechanism and environmental supervision of mining areas after Law No. 3 of 2020. The method of this study method is normative legal research with a case approach. The results of his research conclude, first, the settlement of land rights for mining by the central government will obscure the state's function as regulator and licensee; second, mining environmental permits and supervision have not been based on environmental policies, and there is no implementation of an integrated environmental monitoring system in the regions.
\end{abstract}

Key Words: Environment; mining; land rights; settlement

Abstrak

Undang-Undang Nomor 3 Tahun 2020 tentang Perubahan atas Undang-Undang Nomor 4 tahun 2009 tentang Pertambangan Mineral dan Batubara (UU No. 3 Tahun 2020) mengandung problem substansi. Permasalahannya adalah pertama, mengenai penyelesaian hak atas tanah untuk kegiatan usaha pertambangan mineral dan batubara yang problematik, kedua, mengenai mekanisme perizinan dan pengawasan lingkungan area pertambangan pasca UU No. 3 Tahun 2020. Metode penelitian ini merupakan jenis penelitian hukum normatif dengan pendekatan kasus. Hasil penelitiannya menyimpulkan, pertama, penyelesaian hak atas tanah untuk pertambangan yang dilakukan oleh pemerintah pusat akan mengaburkan fungsi negara sebagai pengatur dan pemberi izin; kedua, perizinan dan pengawasan lingkungan pertambangan belum mendasarkan pada kebijakan lingkungan, dan tidak adanya pemberlakuan sistem pengawasan lingkungan terpadu di daerah..

Kata-kata Kunci: Hak atas tanah; lingkungan; penyelesaian; pertambangan 


\section{Pendahuluan}

Kebijakan pertambangan mineral dan batubara di Indonesia telah mengalami perubahan yang sangat signifikan pasca disahkannya UndangUndang Nomor 3 Tahun 2020 tentang Perubahan atas Undang-Undang Nomor 4 Tahun 2009 tentang Pertambangan Mineral dan Batubara (UU No. 3 Tahun 2020). UU No. 3 Tahun 2020 dibentuk dan disahkan dengan problem yang cukup serius baik dari segi proses pembentukan maupun substansi materi muatannya. Persoalan tersebut diantaranya secara formil dan materiil, yang semestinya masih perlu ada pembahasan atas beberapa materi muatan dari perizinan, konstruksi hukum pusat-daerah dalam pengusahaan pertambangan, penyelesaian hak atas tanah, pengelolaan lingkungan hidup, reklamasi dan pasca tambang, hingga persoalan pengawasan. Sebelum perubahan, sejumlah ketentuan dalam UndangUndang Nomor 4 Tahun 2009 tentang Pertambangan Mineral dan Batubara tidak bisa dioperasionalkan, sehingga mengandung problem yuridis dan problem implementasi, termasuk sistem perizinan dan pengawasan, penyelesaian hak atas tanah, dan pengelolaan lingkungan hidup dalam reklamasi dan pasca tambang.

Persoalan penyelesaian hak atas tanah misalnya dalam ketentuan yang lama menjadi kewajiban pemegang Izin Usaha Pertambangan (IUP) untuk menyelesaikan hak atas tanah dalam kegiatan usaha pertambangan dan dapat dilakukan secara bertahap. Namun, tidak ada konsekuensi yuridis ketika pemegang IUP tidak melaksanakan atau tidak tuntas dalam penyelesaian hak atas tanah. Terutama tanah masyarakat adat sehingga mengarahkan pada tindakan pelanggaran hukum oleh pemegang IUP hingga ancaman pidana bagi warga masyarakat sekitar yang merintangi kegiatan usaha pertambangan atau kriminalisasi, ${ }^{1}$ namun penyelesaian hak atas tanahnya tidak tuntas. Tanggungjawab penyelesaian hak atas tanah untuk kegiatan usaha pertambangan mineral dan batubara terjadi perubahan yang fundamental antara undangundang sebelumnya dengan pasca perubahan. ${ }^{2}$

\footnotetext{
${ }^{1}$ Lihat: Wahyu Nugroho, https://bakaba.co/perampasan-hak-atas-tanah-sebuah-krisis-kemanusiaan-danekolog/, diakses pada tanggal 3 Agustus 2020.

${ }^{2}$ Lihat: Persandingan ketentuan Pasal 136 UU No. 4 tahun 2009 dengan Pasal 137A Undang-Undang Nomor 3 tahun 2020 tentang Perubahan atas Undang-Undang Nomor 4 tahun 2009 tentang Pertambangan Mineral dan Batubara.
} 
Perubahan yang fundamental tersebut tiga diantaranya adalah pertama, konsep wilayah hukum pertambangan sebagai keseluruhan ruang bumi dalam satu wilayah Indonesia yang menggeser prinsip tata ruang nasional dan daerah, sehingga atas konsep tersebut, terjadi peralihan fungsi ruang/kawasan, baik lindung, konservasi, maupun tanah ulayat di kawasan hutan maupun pesisir; kedua, daerah tidak memiliki kewenangan terkait kebijakan pengelolaan lingkungan, dari pengaturan dan perizinan hingga pengawasan, sehingga semakin memperparah kerusakan/pencemaran lingkungan akibat kegiatan usaha pertambangan yang izinnya diperoleh dari pemerintah pusat; dan ketiga, penyelesaian permasalahan hak atas tanah dilakukan oleh pemerintah pusat melalui mediasi, sementara dalam ketentuan yang lama penyelesaian hak atas tanah dilakukan oleh pemegang izin. Ketentuan teknis penyelesaian hak atas tanah diatur dengan Peraturan Pemerintah, sehingga harus menunggu Peraturan Pemerintah (PP) diterbitkan, sementara perencanaan kegiatan usaha pertambangan jalan terus di atas hak atas tanah milik orang lain.

Selain permasalahan tersebut, perizinan dan pengawasan atas instrumen lingkungan dalam kebijakan pengelolaan lingkungan hidup belum berjalan. Beberapa permasalahan serius di daerah berkaitan dengan perizinan adalah terjadinya cacat formil instrumen perizinan lingkungan dalam penyusunan dokumen amdal yang tidak melibatkan masyarakat sekitar yang terdampak langsung, atau tidak memiliki izin amdal, dan perizinan yang tidak diikuti dengan pengawasan, baik pengawas tambang maupun pengawas lingkungan hidup. Tidak dilaksanakannya kewajiban reklamasi \& pasca tambang yang jaminan reklamasinya sudah disertakan pada saat pengajuan izin usaha pertambangan, sehingga pencemaran dan kerusakan lingkungan tidak dapat dihindari.

Konsepsi Wilayah Pertambangan (WP) telah mengalami pergeseran makna dari yang awalnya terintegrasi dengan sistem tata ruang nasional guna memastikan terlaksananya kebijakan lingkungan hidup menjadi bagian dari wilayah hukum pertambangan baik di wilayah darat, laut maupun ruang bumi sebagai landasan dalam penetapan kegiatan usaha pertambangan. Pengertian wilayah hukum pertambangan menurut ketentuan UU No. 3 Tahun 2020 adalah seluruh ruang darat, ruang laut, termasuk ruang dalam bumi sebagai satu 
kesatuan wilayah yakni kepulauan Indonesia, tanah di bawah perairan, dan landas kontinen. ${ }^{3}$ Pergeseran konsep wilayah pertambangan tersebut memiliki implikasi hukum bahwa semua wilayah Indonesia menjadi wilayah hukum pertambangan dan menggeser sistem penataan ruang nasional dalam konteks perlindungan dan pengelolaan lingkungan hidup.

Konsepsi wilayah pertambangan dalam perubahan UU No. 3 Tahun 2020 menjadi ambigu, karena dalam pengertiannya disebutkan bagian dari tata ruang, sementara ketentuan pokoknya menyebutkan wilayah pertambangan sebagai bagian dari wilayah hukum pertambangan. Ketentuan ini menurut penulis "menyamarkan" konsepsi wilayah pertambangan dalam pengertiannya. ${ }^{4}$ Penetapan WP sebagai wilayah hukum pertambangan yang menggeser sistem tata ruang nasional hingga daerah berpotensi memunculkan permasalahan lingkungan yang cukup serius, terlebih ada hak-hak masyarakat atas pengelolaan tanah dalam kawasan hutan yang beririsan dengan tanah ulayat dan hutan adat.

Kompleksitas permasalahan dalam kawasan hutan yang penetapannya oleh pemerintah pusat telah lama terjadi dalam bentuk konflik-konflik tenurial, konflik masyarakat lokal dan masyarakat adat dengan pemegang izin, namun dalam penyelesaian hak atas tanah tidak tuntas. Undang-Undang Nomor 7 Tahun 2012 tentang Penanganan Konflik Sosial menentukan bahwa sumber konflik 2 diantaranya adalah sengketa sumber daya alam antarmasyarakat dan/atau antarmasyarakat dengan pelaku usaha; atau distribusi sumber daya alam yang tidak seimbang dalam masyarakat. ${ }^{5}$

Selain persoalan di atas, kebijakan lingkungan berdasarkan Undang-Undang Nomor 32 Tahun 2009 tentang Perlindungan dan Pengelolaan Lingkungan Hidup (UU No. 32 Tahun 2009) belum ditempatkan sebagai general environmental law, sementara ketentuan pertambangan sebagai sectoral environmental law.

\footnotetext{
3 Lihat: Pasal 1 angka 28a Undang-Undang Nomor 3 Tahun 2020 tentang Perubahan atas UndangUndang Nomor 4 Tahun 2009 tentang Pertambangan Mineral dan Batubara.

4 Dapat dilihat Pasal 1 angka 29 dalam perubahan Undang-Undang No. 3 Tahun 2020 yang mendefinisikan Wilayah Pertambangan (WP) adalah wilayah yang memiliki potensi Mineral dan/atau Batubara dan tidak terikat dengan batasan administrasi pemerintahan yang merupakan bagian dari tata rulang nasional.

${ }^{5}$ Lihat Pasal 5 Undang-Undang Republik Indonesia Nomor 7 Tahun 2012 tentang Penanganan Konflik Sosial. Ketentuan ini tidak implementatif, hal ini dikarenakan setiap undang-undang sektoral terdapat bab yang mengatur mengenai penyelesaian sengketa sesuai dengan objek sengketanya, karena sumber daya alam dipandang sebagai isu sektoral, dan beririsan dengan lingkungan, maka yang menjadi pedomannya adalah ketentuan Undang-Undang Nomor 32 Tahun 2009 tentang Perlindungan dan Pengelolaan Lingkungan Hidup.
} 
Kewenangan pemerintah daerah atas pengaturan, perizinan dan pengawasan dalam kerangka perlindungan dan pengelolaan lingkungan hidup masih diberikan berdasarkan ketentuan UU No. 32 Tahun 2009.

Permasalahan pokok yang dikaji dalam penelitian ini adalah pengaturan penyelesaian hak atas tanah untuk kegiatan usaha pertambangan mineral dan batubara berdasarkan UU No. 3 Tahun 2020 yang menjadi ambigu karena dilakukan oleh pemerintah pusat, sebagai representasi dari negara yang memiliki kewenangan pengaturan dan pengurusan (izin/konsesi), bukan dalam kedudukannya sebagai pemegang IUP. Permasalahan pokok berikutnya adalah berkaitan dengan sistem perizinan dan pengawasan atas kebijakan lingkungan berdasarkan UU No. 3 Tahun 2020 dari segi kewenangan, prosedur perizinan, hingga substansi atas perizinan dan pengawasan lingkungan hidup.

\section{Rumusan Masalah}

Berdasarkan latar belakang di atas, permasalahan dalam penelitian ini adalah pertama, bagaimana persoalan pengaturan penyelesaian hak atas tanah untuk kegiatan usaha pertambangan mineral dan batubara berdasarkan UU No. 3 Tahun 2020? dan kedua, bagaimana sistem perizinan dan pengawasan atas kebijakan lingkungan berdasarkan UU No. 3 Tahun 2020?

\section{Tujuan Penelitian}

Tujuan dalam penelitian ini adalah pertama, untuk menganalisis persoalan pengaturan penyelesaian hak atas tanah untuk kegiatan usaha pertambangan mineral dan batubara berdasarkan UU No. 3 Tahun 2020, dan kedua, untuk menelaah dan menganalisis sistem perizinan dan pengawasan atas kebijakan lingkungan berdasarkan UU No. 3 Tahun 2020.

\section{Metode Penelitian}

Metode yang digunakan dalam penelitian ini adalah penelitian hukum normatif, dengan pendekatan perundang-undangan dan pendekatan kasus. Penelitian ini menggunakan data sekunder yang terdiri dari bahan hukum primer melalui telaah terhadap berbagai ketentuan dalam Undang-Undang Nomor 3 Tahun 2020 tentang Perubahan atas Undang-Undang Nomor 4 Tahun 2009 
tentang Pertambangan Mineral dan Batubara, Undang-Undang Nomor 32 Tahun 2009 tentang Perlindungan dan Pengelolaan Lingkungan Hidup, UndangUndang Nomor 23 Tahun 2014 tentang Pemerintahan Daerah, sedangkan bahan hukum sekundernya menggunakan data yang bersumber dari buku-buku, jurnaljurnal, artikel \& literatur yang relevan. Data-data tersebut kemudian dianalisis secara deskriptif kualitatif.

\section{Hasil Penelitian dan Pembahasan}

\section{Persoalan Pengaturan Penyelesaian Hak atas Tanah untuk Kegiatan Usaha Pertambangan Mineral dan Batubara}

Ketentuan tentang pengakuan hak-hak dasar warga negara terhadap tanah dan sumber daya alam di dalam UUD NRI 1945 mengindikasikan adanya pergeseran konsep negara hukum formalistik menuju konsep substantif. Meskipun ketentuan Pasal 1 ayat (3) UUD NRI 1945 tidak memberikan kejelasan tentang konsep negara hukum apa yang dianutnya, namun keberadaaan Bab XA dan ketentuan Pasal 18B ayat (2) UUD NRI 1945 memberikan petunjuk bahwa konstitusi baru tersebut memaknai negara hukum terkait penguasaan dan pemanfaatan tanah dan kekayaan alam dalam makna substantifnya. ${ }^{6}$

Selain mengatur lebih eksplisit hak-hak dasar warga negara, UUD NRI 1945 juga memuat ketentuan pro-pelestarian lingkungan dalam ketentuan terkait penguasaan negara atas tanah dan kekayaan alam. Pasal 33 ayat (4) UUD NRI 1945 yang menaungi ketentuan hak menguasai negara, sekarang menambah pula ketentuan bahwa perekonomian nasional yang sering menjadi basis argumentasi pentingnya negara menguasai tanah dan kekayaan alam, harus pula berlandaskan pada prinsip pembangunan berkelanjutan. ${ }^{7}$ Dengan demikian jelaslah bahwa pengakuan, perlindungan dan pemenuhan hak asasi manusia serta pelestarian lingkungan hidup kiranya menjadi tujuan dari ketentuan hak menguasai negara dalam UUD NRI 1945. Tujuan ini menegaskan kembali tujuan

${ }^{6}$ Myrna Savitri dan Tristam Moeliono, "Bernegara Hukum dan Berbagi Kuasa dalam Urusan Agraria di Indonesia: Sebuah Pengantar", dalam Hukum Agraria dan Masyarakat di Indonesia, Ed. I, HuMa-Van Vollenhoven Institute-KITLV, Jakarta, 2010, hlm. 11.

${ }^{7}$ Ibid. 
bernegara untuk melindungi segenap bangsa dan tumpah darah serta mewujudkan keadilan sosial bagi seluruh rakyat Indonesia.

Mahkamah Konstitusi (MK) menafsirkan konsep hak menguasai negara atas sumber daya alam berdasarkan Pasal 33 ayat (3) UUD NRI 1945 yakni:

...Rakyat secara kolektif itu dikonstruksikan oleh UUD 1945 memberikan mandat kepada negara untuk mengadakan kebijakan (beleid) dan tindakan pengurusan (bestuursdaad), pengaturan (regelendaad), pengelolaan (beheersdaad) dan pengawasan (toezichthoudensdaad) untuk tujuan sebesar-besarnya kemakmuran rakyat. ${ }^{8}$

Berdasarkan tafsir MK terkait penguasaan negara atas sumber daya alam tersebut dapat dipahami bahwa pemaknaan terhadap penguasaan oleh negara telah tegas dan jelas, sehingga setiap undang-undang di bidang sumber daya alam, baik undang-undang baru maupun undang-undang perubahan harus menjadikan asas penguasaan negara atas sumber daya alam sebagai asas dalam pengusahaan sumber daya alam. Adapun bentuk pengusahaan dengan berlandaskan asas pengusahaan negara tersebut, yang dapat termanifestasi ke dalam 3 cara berikut: ${ }^{9}$ a. penguasaan dan pengusahaan yang dilakukan sendiri oleh negara; b. penguasaan oleh negara dan pengusahaan oleh swasta; atau c. penguasaan oleh negara dan pengusahaan oleh perusahaan negara.

Hak-hak tanah yang diberikan kepada investor diantaranya seperti Hak Guna Usaha (HGU), Hak Guna Bangunan (HGB), dan Hak Pakai. Dalam hal pemberian hak atas tanah yang merupakan kewenangan negara muncul tuntutan adanya penyesuaian substansinya. Kondisi ini menciptakan kesenjangan antara amanat dan cita-cita Undang-Undang No. 5 Tahun 1960 tentang Peraturan Dasar Pokok-Pokok Agraria (UUPA) dengan pelaksanaan atau realita yang berlangsung. Kesenjangan ini ditandai oleh ketidakkonsistenan antara amanat dan semangat prinsip-prinsip UUPA dengan penjabaran dalam peraturan pelaksanaannya. Sejumlah peraturan pelaksanaan mencerminkan insinkronisasi adalah: ${ }^{10}$

${ }^{8}$ Lihat: Putusan Mahkamah Konstitusi Perkara Nomor 001-021-022/PUU-I/2003 Pengujian UndangUndang Nomor 20 Tahun 2002 tentang Ketenagalistrikan terhadap Undang-Undang Dasar Negara Republik Indonesia Tahun 1945, hlm. 334.

9 Ahmad Redi, "Dinamika Konsepsi Penguasaan Negara atas Sumber Daya Alam", Jurnal Konstitusi, Volume 12, Nomor 2, Juni 2015, hlm. 410.

10 Natanael Dwi Reki, "Pembatasan Pemilikan dan Penguasaan Hak atas Tanah dalam Perspektif Reforma Agraria", Jurnal Hukum Magnum Opus, Volume I, Nomor 1, Agustus 2018, hlm. 38. 
a. pemberian tanah yang luas kepada pengusaha di sektor perkebunan, kehutanan dan properti sehingga menimbulkan akumulasi penguasaan tanah;

b. ketentuan yang mendorong pemahaman bahwa tanah itu merupakan komoditi dan mengabaikan hak lainnya seperti fungsi sosial dan nilai religius;

c. ketentuan yang mendorong tentang pengabaian terhadap hak-hak tradisional atas tanah masyarakat adat;

d. peraturan yang memberi peluang terjadinya pengabaian dan kemerosotan kesejahteraan;

e. pemegang hak atas tanah yang terkena pengambilalihan untuk kepentingan pembangunan.

Kebijakan pertambangan mineral dan batubara hendaknya mempertimbangkan karakter pluralisme hukum. Pluralisme hukum sebagaimana dikonsepsikan oleh Ida Nurlinda dalam bingkai unifikasi hukum perlu adanya penghormatan terhadap sistem hukum adat terkait penggunaan objek tanah yang bukan semata diorientasikan pada proyek strategis nasional, sementara Sulistyowati Irianto memberikan istilah sebagai "hukum yang bergerak".11 Pluralisme hukum bercirikan keberagaman diantara sistem hukum di negara Indonesia menunjukkan bahwa adanya suatu hak-hak pengelolaan tanah masyarakat tradisional dan masyarakat hukum adat yang juga dihormati oleh negara, termasuk dalam proses penyelesaian hak atas tanah untuk kegiatan usaha pertambangan.

Penyelesaian hak atas tanah yang dilakukan oleh pemerintah berdasarkan ketentuan UU No. 3 Tahun 2020 hendaknya juga memerhatikan pengakuan hak atas tanah masyarakat hukum adat, sekalipun hak menguasai negara terhadap kandungan bawah tanah berupa mineral dan batubara dikelola oleh negara atau pihak ketiga melalui izin. Peraturan Menteri Agraria dan Tata Ruang/Kepala Badan Pertanahan Nasional No. 18 Tahun 2019 tentang Tata Cara Penatausahaan Tanah Ulayat Kesatuan Masyarakat Hukum Adat, menyimplifikasi regulasi dan pemaknaan kembali istilah tanah ulayat dari pengaturan sebelumnya. ${ }^{12}$ Ketentuan

${ }^{11}$ Lihat: Ida Nurlinda, Monograf Hukum Agraria Membangun Pluralisme Hukum dalam Kerangka Unifikasi Hukum Agraria, Cet. I, Pusat Studi Hukum Lingkungan dan Penataan Ruang Fakultas Hukum Universitas Padjadjaran \& Logoz Publishing, Bandung, 2014, hlm. 45. Bandingkan juga dengan Sulistyowati Irianto, Hukum Yang Bergerak, Tinjauan Antropologi Hukum, Cet. I, Yayasan Obor Indonesia, Jakarta, 2009, hlm. 29-30.

12 Pengaturan sebelumnya yang dimaksud adalah Peraturan Menteri Agraria Nomor 9 Tahun 2015 tentang Tata Cara Penetapan Hak Komunal Atas Tanah Masyarakat Hukum Adat dan Masyarakat yang Berada 
tersebut mengatur penatausahaan tanah ulayat masyarakat hukum adat, namun harus terlebih dahulu ada ketetapan pengakuan dan perlindungan Kesatuan Masyarakat Hukum Adat. ${ }^{13}$ Sementara rancangan undang-undang tentang pengakuan masyarakat hukum adat dalam Program Legislasi Nasional (Prolegnas) prioritas sebagai usulan dari DPR RI,14 yang di dalamnya memuat ketentuan penetapan pengakuan dan perlindungan Kesatuan Masyarakat Hukum Adat hingga saat ini belum ditindaklanjuti pembahasannya di DPR untuk kemudian disahkan.

Berdasarkan Peraturan Menteri Agraria tersebut, sebelum ditetapkan penatausahaan tanah ulayat sebagi objek, terlebih dahulu ada penetapan atas pengakuan subjek, yakni masyarakat hukum adat. Hal ini menjadi masalah, ketika suatu wilayah/daerah belum ada penetapan subjek, padahal eksistensi secara fakta sosiologisnya ada dan belum ada perlindungan atas tanah yang memiliki potensi kandungan mineral dan batubara. Kebijakan pada saat penetapan Wilayah Pertambangan (WP) erat kaitannya dengan perlindungan masyarakat yang terdampak dan pelestarian lingkungan, sehingga sangat menentukan nasib tanah dan hak-hak yang melekat pada kelompok tradisional atau masyarakat hukum adat dalam wilayah pertambangan yang menjadi rezim hukum pertambangan. ${ }^{15}$

Perubahan ketentuan Pasal 9 UU No. 3 Tahun 2020 terkait Wilayah Pertambangan yang merupakan Wilayah Hukum Pertambangan tidak memerhatikan kebijakan penataan ruang nasional. Sementara wilayah hukum pertambangan dalam ketentuan tersebut masuk di semua wilayah, baik darat, laut maupun ruang bumi. Hal ini berpotensi menimbulkan perubahan suatu ruang atau kawasan untuk kegiatan usaha pertambangan mineral dan batubara.

\footnotetext{
Dalam Kawasan Tertentu, dan Peraturan Menteri Agraria Nomor 5 Tahun 1999 tentang Pedoman Penyelesaian Masalah Hak Ulayat Masyarakat Hukum Adat.

${ }^{13}$ Lihat: Pasal 5 ayat (2) Peraturan Menteri Agraria dan Tata Ruang/Kepala Badan Pertanahan Nasional Republik Indonesia Nomor 18 tahun 2019 tentang Tata Cara Penatausahaan Tanah Ulayat Kesatuan Masyarakat Hukum Adat menyatakan: Penatausahaan Tanah Ulayat Kesatuan Masyarakat Hukum Adat sebagaimana dimaksud pada ayat (1) dilakukan berdasarkan penetapan pengakuan dan perlindungan Kesatuan Masyarakat Hukum Adat sebagaimana dimaksud dalam Pasal 3.

14 Lihat Program Legislasi Nasional Prioritas tahun 2020: http://www.dpr.go.id/uu/prolegnas, diakses tanggal 4 Agustus 2020.

15 Putusan MK No. Nomor 32/PUU-VIII/2010 atas Pengujian Undang-Undang Nomor 4 Tahun 2009 tentang Pertambangan Mineral dan Batubara terhadap Undang-Undang Dasar Negara Republik Indonesia Tahun 1945, terkait dengan peran serta masyarakat yang terdampak, mahkamah mengabulkan secara bersyarat sepanjang tidak dimaknai, "wajib melindungi, menghormati, dan memenuhi kepentingan masyarakat yang wilayah maupun tanah miliknya akan dimasukkan ke dalam wilayah pertambangan dan masyarakat yang akan terkena dampak", hlm. 143.
} 
Penataan ruang yang menjamin bahwa dipenuhinya prinsip pembangunan berwawasan lingkungan sesuai dengan peruntukan fungsi ruang atau kawasan. Atas dasar wilayah hukum pertambangan, fungsi lindung dan konservasi, hingga tanah ulayat dan hutan adat yang didalamnya terkandung kearifan lokal dianggap sebagai wilayah hukum pertambangan yang legitimasi dimiliki oleh negara untuk dikuasai dan dikelola.

Temuan hasil disertasi penulis menyatakan bahwa hukum sebagai sarana pembaharuan masyarakat dalam konteks penguasaan negara atas pertambangan, konsep integrasinya adalah melalui penetapan Wilayah Pertambangan (WP) dengan pemetaan atas wilayah adat dan mempertimbangkan hak ulayat di kawasan hutan, perkebunan, kawasan pesisir dan pulau-pulau kecil yang terumuskan dalam sistem penataan ruang nasional dan menjadi pedoman dalam penyusunan Rencana Tata Ruang dan Wilayah (RTRW) daerah Provinsi, Kabupaten/Kota dengan tujuan perlindungan masyarakat hukum adat dan berorientasi pada falsafah atau nilai-nilai keseimbangan antara Tuhan Sang Pencipta, objek ciptaannya berupa alam semesta, dan kepentingan manusia. ${ }^{16}$

Hasil kajian Moh. Jamin mengungkap bahwa keragaman dalam bentuk kearifan lokal yang secara empiris hidup dari generasi ke generasi sebagai komunitas lokal merupakan aset sosial yang dapat diberdayakan dalam resolusi konflik sosial. Kearifan lokal memiliki dua peran penting, yaitu mencegah konflik sosial dan sekaligus memberikan solusi terkait penyelesaian konflik sosial yang dimilikinya. ${ }^{17}$

Politik hukum pembentukan UU No. 3 Tahun 2020 memiliki problem yuridis dan sosiologis terkait penyelesaian hak atas tanah. Sementara selama ini pemerintah belum mampu melakukan mediasi atas konflik pertanahan di sektor pertambangan guna memberikan keadilan masyarakat dalam mengakses hak atas tanahnya. Advokasi yang pernah penulis lakukan 2019 di Kalimantan Timur adalah upaya penyelesaian permasalahan konflik pertanahan melalui mediasi

16 Wahyu Nugroho, Ringkasan Disertasi, "Konsep Integrasi Kebijakan Pertambangan Nasional Dengan Masyarakat Hukum Adat dalam Mewujudkan Keadilan Ekologis", Program Doktor Ilmu Hukum Universitas Padjadjaran, Bandung, Tahun 2019, hlm. 114.

17 Mohammad Jamin, "Social Conflict Resolution Through Empowerment of Local Wisdoms", Yustisia Jurnal Hukum, Volume 9 Nomor 1, Januari-April 2020, hlm. 17. 
antara warga masyarakat pemilik lahan dengan pihak perusahaan dan aparat pemerintah maupun penegak hukum, beberapa kali mengalami deadlock dan gagalnya upaya mediasi oleh pemerintah.

Kasus di Kabupaten Berau Provinsi Kalimantan Timur, ${ }^{18}$ pada intinya masyarakat individu maupun kelompok tani dan Sultan sebagai pemilik lahan yang diatasnya terdapat kegiatan usaha pertambangan batubara belum dilakukan pembayaran kompensasi lahan milik kelompok tani yang masuk dalam Kawasan Budidaya Non Kehutanan (KBNK). Belum tuntasnya penyelesaian hak atas tanah kemudian berimplikasi pada kerusakan lingkungan dan perubahan bentang alam diatas lahan warga dan kelompok tani, sehingga tidak mendapatkan daya dukung dan daya tampung lingkungan hidup. Selain itu, manajemen konflik seringkali digunakan untuk memecah belah dua kelompok warga yang ingin mendapatkan kompensasi lahan tersebut, sehingga bukan hanya terjadi konflik vertikal dengan pemerintah dan perusahaan, melainkan konflik horizontal antara sesama kelompok warga masyarakat.

Pengesahan RUU Minerba yang sekarang menjadi UU No. 3 Tahun 2020, terjadi pengabaian terhadap ideologi sumber daya alam sebagaimana tertuang dalam Pasal 33 UUD NRI 1945. Pasal 169A UU Minerba mengatur mengenai perpanjangan perusahaan pemegang Kontrak Karya (KK) dan Perjanjian Karya Pengusahaan Batubara (PKP2B) dengan Izin Usaha Pertambangan Khusus (IUPK) tanpa adanya pemberian prioritas kepada BUMN dan BUMD untuk mengusahakannya. Ketidakberpihakan pemerintah dan DPR dalam UU Minerba merupakan bentuk kezaliman negara terhadap perusahaan negara yang dimiliki negara itu sendiri, kecuali bila pengendali negara telah tersendera karena adanya konflik kepentingan dengan usaha-usahanya atau kelompoknya. ${ }^{19}$

UU No. 3 Tahun 2020 semakin memperparah permasalahan dalam konteks penyelesaian hak atas tanah yang dilakukan oleh pemerintah pusat. Sementara kebijakan pengelolaan lingkungan hidup dalam ketentuan UU No. 32 Tahun 2009 dilakukan oleh pemerintah pusat, pemerintah daerah provinsi dan pemerintah

\footnotetext{
${ }^{18}$ Lihat: Ikbal Nurkarim, Tuntut Ganti Rugi Laban, Ratusan Warga Kabupaten Berau Unjuk Rasa di Lokasi Tambang Batu Bara, https://kaltim.tribunnews.com/2020/02/10/tuntut-ganti-rugi-lahan-ratusan-wargakabupaten-berau-unjuk-rasa-di-lokasi-tambang-batu-bara?page=all, diakses pada tanggal 26 Oktober 2020.

${ }^{19}$ Lihat: Ahmad Redi, https://analisis.kontan.co.id/news/menguji-konstitusionalitas-uu-minerba, diakses pada tanggal 6 Agustus 2020.
} 
daerah kabupaten/kota. Penyelesaian hak atas tanah untuk kegiatan usaha pertambangan ini mengandung permasalahan norma dan implementasinya.

Permasalahan norma dapat dilihat dalam ketentuan Pasal 137A ayat (1) UU No. 3 Tahun 2020. Pemerintah Pusat melakukan penyelesaian permasalahan hak atas tanah untuk kegiatan Usaha Pertambangan sebagaimana dimaksud dalam Pasal 134, Pasal 135, Pasal 136, dan Pasal 137. Sementara pada ayat (2) menyatakan ketentuan lebih lanjut mengenai penyelesaian hak atas tanah sebagaimana dimaksud pada ayat (1) diatur dengan Peraturan Pemerintah. Dalam penjelasannya, penyelesaian permasalahan hak atas tanah dilakukan oleh Pemerintah Pusat melalui mediasi dalam hal tidak tercapainya kesepakatan antara Pemegang IUP atau IUPK dengan pemegang hak atas tanah. Ketentuan ini akan menimbulkan ambiguitas tafsir hak menguasai negara sebagaimana yang ditafsirkan oleh MK. Selain hal tersebut, ketentuan Pasal 137A ayat (2) UU No. 3 Tahun 2020 masih menunggu pengaturan lebih lanjut dalam Peraturan Pemerintah (PP), sementara konflik pada saat proses pelepasan hak atas tanah terus terjadi. Peralihan kewajiban penyelesaian hak atas tanah dari pemegang IUP oleh negara berpotensi menimbulkan "lorong gelap" atau "kabut tebal" dalam proses perizinan yang berada di pusat dan menempatkan negara sebagai pengusaha.

Pihak yang akan melakukan kegiatan usaha pertambangan dalam pengusahaan pertambangan tidak dapat secara langsung melakukan penggalian atau pengeboran tanah karena lokasi tersebut terdapat pemilik hak atas tanah. Sedangkan pemilik hak atas tanah pada umumnya juga tidak dengan mudah memberikan izin kepada orang lain untuk memasuki pekarangannya dan melakukan penambangan. Apalagi hak atas tanah lebih dahulu diberikan daripada hak atas pertambangan. Bahkan kegiatan pengerukan tanah dalam kegiatan pertambangan juga mengandung risiko besar karena permukaan tanah akan mengalami penurunan/ambles. ${ }^{20}$

Pemegang hak atas pertambangan baru melaksanakan kegiatan eksplorasi pertambangan apabila pemegang hak atas tanah memberikan persetujuannya. Persetujuan tersebut dapat dalam bentuk lisan atau tertulis lazimnya berupa

${ }^{20}$ Gatot Supramono, Hukum Pertambangan Mineral dan Batu Bara di Indonesia, PT Rineka Cipta, Jakarta, 2012, hlm. 185. 
perjanjian oleh karena latar belakang kegiatan pertambangan untuk kepentingan bisnis, tidak tertutup pemegang hak atas tanah meminta imbalan dari pihak pemegang hak atas pertambangan yang besarnya sesuai dengan kesepakatan dan dimasukkan sebagai salah satu klausula dalam perjanjian. Jika pemegang hak atas tanah menolak untuk memberikan persetujuan maka pihak pemegang hak atas pertambangan tidak dapat memaksanya. Agar haknya tidak hapus atau sia-sia, pemegang hak atas pertambangan harus dapat menyelesaikan persoalan dengan jalan damai dan mengutamakan keamanan dan ketentraman masyarakat. ${ }^{21}$

Kebijakan dalam konteks penyelesaian hak atas tanah untuk kegiatan usaha pertambangan mineral dan batubara menurut perubahan UU No. 3 Tahun 2020, harus tetap memerhatikan ketentuan dalam UUPA. Hal ini harus dipandang bagian integral dari pengaturan hak atas tanah sebagaimana yang diatur dalam Pasal 16 dan Pasal 54 UUPA, yaitu hak atas tanah yang bersifat tetap, dan hak atas tanah yang bersifat sementara. Kegiatan usaha pertambangan sekalipun dilakukan dalam kandungan bumi, namun akan menjadi masalah apabila penyelesaian sengketa atas tanah masih belum tuntas, apalagi jika terjadi konflik lahan.

Selain permasalahan regulasi, terdapat juga problem implementasi. Beberapa perubahan atas ketentuan di bidang pertambangan sejak awal hingga sekarang ini masih menimbulkan konflik agraria di sektor pertambangan terkait pengusahaan pertambangan mineral dan batubara. Berdasarkan data yang dihimpun oleh Konsorsium Pembaruan Agraria (KPA) melalui catatan akhir 2019, menyatakan sektor pertambangan menyumbangkan letusan konflik sebanyak 24 konflik yang terbagi ke dalam konflik tambang batu bara sebanyak 5 konflik, tambang emas 5 konflik, tambang nikel 5 konflik, tambang pasir 5 konflik, timah 2 konflik dan migas 2 konflik. 22

Berbagai konflik tersebut dipicu beberapa norma yang tidak implementatif dalam ketentuan yang lama. Misalnya, pertama, ketentuan pidana bagi tambang illegal yang berlaku untuk semua jenis pertambangan, sehingga termasuk didalamnya tambang pasir dan batu yang dilakukan secara illegal, khususnya masyarakat menengah ke bawah, maka proses pidananya tidak berjalan, atau jika

${ }^{21}$ Hayatul Ismi, "Hak Atas Tanah dalam Pengelolaan Sumber Daya Alam Mineral dan Batubara", Jurnal Ilmu Hukum, Vol. 4 No. 2, Februari-Juli 2014, hlm. 250.

22 Catatan Akhir Tahun 2019 Konsorsium Pembaruan Agraria, hlm. 13-14. 
berjalan, hanya di tingkat penyidikan saja. Hal tersebut dikarenakan warga sangat terdesak melakukannya untuk kebutuhan makan sehari-hari, dan membutuhkan waktu yang lama apabila izinnya ke pemerintah pusat atau didelegasikan ke pemerintah provinsi sesuai kewenangannya; kedua, ketentuan kewajiban reklamasi dan pasca tambang dalam rangka pemulihan lingkungan hidup yang tidak diikuti dengan ketentuan sanksi pidana bagi pemegang IUP yang tidak memenuhi kewajiban tersebut; dan ketiga, pengaturan tentang penyelesaian hak atas tanah yang dilakukan secara bertahap oleh pemegang IUP, ternyata tidak tuntas, sehingga berimplikasi pada pemidanaan warga masyarakat yang mempertahankan hak atas lingkungan hidup di lahan produktifnya. Ketentuan pidana ini masih dipertahankan dalam perubahan UU Minerba No. 3 Tahun 2020, bahwa setiap orang yang merintangi atau mengganggu kegiatan Usaha Pertambangan dari pemegang IUP, IUPK, IPR, atau SIPB yang telah memenuhi syarat-syarat sebagaimana dimaksud dalam Pasal 136 ayat (2) dipidana dengan pidana kurungan paling lama 1 tahun atau denda paling banyak Rp. 100.000.000,00.

Berbagai ketentuan yang tidak implementatif akan menimbulkan multitafsir dan perbedaan pemahaman oleh pemerintah dan aparat penegak hukum, sehingga mengakibatkan konflik agraria di sektor pertambangan. Perubahan UU Minerba dalam UU No. 3 Tahun 2020 justru memperparah ketentuan tersebut, sehingga ke depan sebagai ius constituendum atas politik hukum pembentukan UU Minerba perlu diperbaiki. Pertama, norma berkaitan dengan diberikannya kembali kewenangan kabupaten/kota khusus untuk izin pertambangan rakyat dengan model edukasi, pembinaan dan pengawasan secara terpadu, sehingga tidak terjadi praktik penambangan illegal oleh masyarakat golongan menengah ke bawah; kedua, adanya keseimbangan antara kewajiban reklamasi dan pasca tambang dalam rangka pemulihan lingkungan hidup dengan ketentuan sanksi pidana bagi yang tidak melaksanakan kewajiban reklamasi; dan ketiga, penyelesaian hak atas tanah yang tidak tuntas, ada hak masyarakat untuk tetap melakukan pengelolaan di atas lahannya sendiri, sehingga tidak ada tindakan memidanakan warga masyarakat yang mempertahankan hak atas lingkungan 
hidup yang justru kontradiktif terhadap ketentuan dalam UU No. 32 Tahun 2009, sementara di sisi lain, ada sanksi pidana bagi pemegang izin yang tuntas dalam penyelesaian hak atas tanah.

Sebelum melakukan aktivitas operasional tambang, perusahaan tambang pada umumnya melakukan kompensasi ganti kerugian atas lahan-lahan produktif masyarakat yang berada di wilayah Izin Pinjam Pakai Kawasan Hutan. Pemberian kompensasi ini diperuntukan bagi masyarakat pemilik lahan yang memang benar memiliki lahan tersebut dengan berdasarkan surat keterangan tanah. Berdasarkan surat tersebut perusahaan mau memberikan kompensasi ganti kerugian berupa sejumlah uang sesuai dengan nilai kesepakatan para pihak, sehingga diharapkan dengan adanya penggantian kerugian lahan bagi pemilik lahan sebenarnya perusahaan dapat menjalankan kegiatan operasionalnya tanpa ada halangan apapun yang berakibat terjadinya sengketa lahan. ${ }^{23}$

Kasus sengketa yang berujung pada tumpang tindih lahan merupakan sengketa yang melibatkan beberapa orang atau kelompok tani di satu area lahan. Masing-masing orang atau kelompok tani memiliki bukti-bukti kepemilikan lahan ditambah lagi dari pihak perusahaan telah melakukan pembebasan lahanlahan tersebut dengan bukti Surat Pernyataan Pelepasan Hak yang dikeluarkan oleh pemilik lahan dan pihak kepala desa/kelurahan maupun kecamatan. ${ }^{24}$

Tindakan pemerintah untuk berinvestasi di bidang usaha tambang sah adanya sebagaimana telah diregulasikan. Tetapi pola kelestarian hidup hayati, ekonomi rakyat, dan perlindungan hak atas tanah harus dijaga dan dilindungi, terutama hak milik. Rakyat butuh perlakuan yang adil dan keseimbangan antara dunia usaha investasi tambang oleh negara dan perlindungan hak milik atas tanah rakyat. Hak milik atas tanah rakyat yang dipergunakan untuk kepentingan umum pembangunan, wajib hukumnya menerapkan prinsip asas keadilan atas pemberian ganti rugi lahan kepada pemilik tanah, termasuk benda-benda yang berada diatasnya baik bangunan atau tanaman. Namun jika itu berkaitan dengan pengolahan investasi tambang swasta (korporasi) berupa penanaman modal

${ }^{23}$ Budi Harjanto, Sukirno, \& Irma Cahyaningtyas, "Penyelesaian Sengketa Lahan Masyarakat di Konsensi Tambang PT. Mahakam Sumber Jaya Kabupaten Kutai Kertanegara”, NOTARIUS, Volume 12 Nomor 1, 2019, hlm. 190.

24 Ibid., hlm. 191. 
dalam atau luar negeri (asing), maka penyelesaiannya dengan mekanisme tersendiri. ${ }^{25}$ Prinsip yang wajib dipertahankan adalah investasi lahan tambang tidak boleh menciderai pengakuan hak milik atas tanah rakyat, sehingga apabila jika berjalan beriringan, maka akan terwujud kesejahteraan ekonomi rakyat. ${ }^{26}$

Persoalan dalam penyelesaian hak atas tanah untuk kegiatan usaha pertambangan mineral dan batubara berdasarkan UU No. 3 Tahun 2020 sangat kompleks baik dalam tataran norma seperti yang sebelumnya telah penulis kemukakan maupun implementasinya. Permasalahan konflik pertanahan untuk kompensasi ganti rugi atau ganti untung atas lahan warga masyarakat yang wilayahnya dijadikan sebagai lokasi kegiatan usaha pertambangan mineral dan batubara, memidanakan warga masyarakat yang mempertahankan hak atas lingkungan hidup atau ruang hidupnya, bahkan data yang dihimpun Jaringan Advokasi Tambang (Jatam) terdapat 71 konflik pertambangan periode 2014-2019.27 Perampasan atau penggusuran hak bertempat tinggal dan lahan kelola warga masyarakat, ${ }^{28}$ dengan dalih objek vital nasional atau kawasan strategis nasional.

Selain itu, kerusakan lingkungan melalui perubahan bentang alam terjadi karena tidak ada perencanaan dan partisipasi masyarakat yang terdampak langsung sejak pada tahap penentuan WP. Permasalahan implementasi ketentuan pertambangan juga menjadikan kelompok masyarakat terbelah dua karena menggunakan manajemen konflik yang diciptakan perusahaan, serta mengakibatkan kerusakan ekosistem, penebangan pohon dalam kawasan hutan dan hilangnya habitat satwa, sebagai akibat dari perizinan yang tidak partisipatif dan tidak memiliki desain tata ruang yang terintegrasi dengan Kajian Lingkungan Hidup Strategis (KLHS).

Penyelesaian hak atas tanah yang dilakukan oleh pemerintah pusat dan ditindaklanjuti dalam bentuk Peraturan Pemerintah sangat bias sehingga akan

25 Nala Natasya, "Investasi Tambang dan Perlindungan Hak Milik atas Tanah Rakyat", dalam opininya tanggal 14 Juni 2020 melalui https://detiksultra.com/investasi-tambang-dan-perlindungan-hak-milik-atas-tanahrakyat/, diakses tanggal 27 Agustus 2020.

${ }^{26} \mathrm{Ibid}$.

27 Lihat: Ady Thea DA, Jatam: Ada 71 Konflik Pertambangan Periode 2014-2019, https://www.hukumonline.com/berita/baca/lt5e14311f6aa5a/jatam--ada-71-konflik-pertambangan-periode2014-2019/, diakses pada tanggal 26 Oktober 2020.

${ }^{28}$ Lihat: Kamarudin dan Della Syahni, Sulitnya Warga Wawonii Pertahankan Lahan dari Perusahaan Tambang, $\quad$ https://www.mongabay.co.id/2019/09/19/sulitnya-warga-wawonii-pertahankan-lahan-dariperusahaan-tambang/, diakses pada tanggal 26 Oktober 2020. 
mengaburkan fungsi negara sebagai pengatur (regelendaad) dan pemberi izin (bestuursdaad), serta berpotensi melahirkan politik transaksional di pemerintah pusat, sementara pemegang IUP tidak dibebankan kewajiban penyelesaian permasalahan hak atas tanah. Selain itu, dalam penjelasannya penyelesaian baru kemudian dilakukan oleh pemerintah melalui mediasi apabila tidak tercapainya kesepakatan antara Pemegang IUP atau IUPK dengan pemegang hak atas tanah.

\section{Kebijakan Lingkungan di Bidang Pertambangan Mineral dan Batubara Berdasarkan Undang-Undang No. 3 Tahun 2020}

Kebijakan lingkungan mendasarkan pada UU No. 32 Tahun 2009 sebagai general environmental law atas ketentuan sumber daya alam sektoral, termasuk pertambangan mineral dan batubara. Kegiatan usaha pertambangan mineral dan batubara memiliki dampak yang cukup serius terhadap lingkungan hidup, sehingga dipandang secara holistik dengan menundukkan pada ketentuan UU No. 32 Tahun 2009 atas kebijakan sektoral sumber daya alam. Ada kewajiban dalam pengusahaan pertambangan mineral dan batubara untuk menjalankan fungsi pengendalian dari adanya pencemaran dan/atau kerusakan lingkungan yang terintegrasi dengan sistem tata ruang hidup sejak penetapan wilayah pertambangan hingga kewajiban menyusun dokumen lingkungan, serta kewajiban melaksanakan reklamasi dan pascatambang.

Penentuan wilayah yang dilakukan secara hukum mengingkari proses sosial penggunaan, penghunian ruang dan proses ekologis didalamnya. Pengaturan pemanfaatan kawasan ruang di kawasan budi daya seperti eksploitasi pertambangan, budi daya kehutanan, budi daya pertanian, dan kegiatan pembangunan permukiman, industri, pariwisata dan lain-lain yang sejenis, sehingga tercapai tata ruang kawasan budi daya. Dengan demikian, dalam pembentukan penataan ruang atau struktur tata ruang harus ada keserasian antara sumberdaya alam hayati dan nonhayati, sehingga timbul keseimbangan fungsi ruang. Merosotnya kualitas lingkungan salah satunya disebabkan oleh penggunaan ruang yang tidak sesuai dengan kondisi lingkungan dan potensi wilayah. ${ }^{29}$ Oleh karena itu, perlu disinergikan dengan regulasi di bidang lingkungan hidup melalui UU No. 32

${ }_{29}$ Rahayu Subekti, Lego Karjoko, dan Wida Astuti, "Kebijakan Tata Ruang di Kabupaten Kutai Kartanegara (Studi Valorisasi Ruang)", Yustisia Jurnal Huk.um, Vol.2 No.2, Mei - Agustus 2013, hlm. 45. 
Tahun 2009 yang mengatur Kajian Lingkungan Hidup Strategis (KLHS). Kajian tersebut dilakukan oleh pemerintah dan pemerintah daerah untuk menetapkan daerah tersebut masuk dalam zona terbuka hijau atau memiliki kelayakan untuk dilakukannya aktivitas perindustrian. ${ }^{30}$

UU No. 3 Tahun 2020 menggabungkan dan menyederhanakan IUP dengan tahapan kegiatan eksplorasi yang meliputi Penyelidikan Umum, Eksplorasi, dan Studi Kelayakan, kemudian Operasi Produksi yang meliputi kegiatan Konstruksi, Penambangan, Pengolahan dan/atau Pemurnian atau Pengembangan dan/atau Pemanfaatan, serta Pengangkutan dan Penjualan. Pasal 39 huruf k UU No. 3 Tahun 2020 menentukan bahwa salah satu muatan IUP Eksplorasi dan Operasi Produksi adalah adanya kewajiban melaksanakan reklamasi dan pascatambang serta menyusun dokumen lingkungan. Penulis berpendapat bahwa tidak ada pemisahan antara berbagai instrumen lingkungan sebagaimana secara mutatis mutandis berlaku ketentuan UU No. 32 Tahun 2009 pada setiap perencanaan kegiatan usaha pertambangan. Secara ideal, pemegang IUP sudah menjalankan instrumen lingkungan terlebih dahulu sebelum melakukan pengurusan terhadap izin usaha.

Kebijakan lingkungan berdasarkan UU No. 32 Tahun 2009 dalam konteks perizinan dan pengawasan atas kegiatan usaha yang berdampak penting terhadap lingkungan dan ekosistem lain dalam suatu wilayah pertambangan, memiliki peran yang cukup sentral. Pasal 18A ayat (2) UUD NRI 1945 mengonstruksikan pemanfaatan sumber daya alam dan sumber daya lainnya antara pemerintah pusat dan pemerintah daerah diatur dan dilaksanakan secara adil dan selaras berdasarkan undang-undang. Ketentuan tersebut kemudian diturunkan ke dalam Undang-Undang Nomor 23 Tahun 2014 tentang Pemerintahan Daerah (UU No. 23 Tahun 2014) yang mengatur pembinaan dan pengawasan pemerintah pusat kepada pemerintah daerah di bidang lingkungan hidup. Pasal 63 UU No. 32 Tahun 2009 mengatur tugas dan wewenang pemerintah dan pemerintah daerah dalam konteks perlindungan dan pengelolaan

30 Wahyu Nugroho, "Reorientasi Kebijakan Pemerintah Daerah dalam Penerapan Otonomi Daerah di Bidang Pertanahan dan Penataan Ruang”, Jurnal Legislasi Indonesia, Vol. 12 No. 2, 2015, hlm. 4. 
lingkungan hidup sesuai dengan kewenangan di masing-masing tingkatan dari pusat, daerah provinsi, dan kabupaten/kota.

UU No. 3 Tahun 2020 tidak mengatur konstruksi hubungan pusat-daerah dalam konteks perizinan dan pengawasan lingkungan sebagaimana diatur dalam UUD NRI 1945, UU No. 23 Tahun 2014 dan UU No. 32 Tahun 2009. Pemerintah Daerah Provinsi dalam penetapan Wilayah Pertambangan (WP) berperan sentral untuk menentukan suatu wilayah pertambangan sebagai akibat hukum dari putusan MK. ${ }^{31}$ Namun Pemerintah Daerah Provinsi harus memerhatikan aspirasi, masukan, saran dan pertimbangan dari Pemerintah Daerah Kabupaten/Kota, atau aspirasi masyarakat daerah kabupaten yang terdampak secara langsung. Pelaksanaan atas penetapan wilayah pertambangan sebagaimana diatur dalam Pasal 10 ayat (2) UU No. 3 Tahun 2020 adalah secara terpadu dengan mengacu pada pendapat dari instansi pemerintah terkait, masyarakat terdampak, dan dengan mempertimbangkan aspek ekologi, ekonomi, hak asasi manusia, dan sosial budaya, serta berwawasan lingkungan; dan dengan memperhatikan aspirasi daerah. ${ }^{32}$

Perizinan dan pengawasan dalam konteks perlindungan dan pengelolaan lingkungan hidup adalah satu-kesatuan, bukan terpisah. Sudah seharusnya diperkuat pranata/kelembagaan lingkungan daerah dan dipertegas penaatan atas instrumen lingkungan hidup sebagai fungsi pengendalian. Kelemahan selama ini adalah fungsi pengawasan di daerah yang tidak berjalan maksimal, baik Dinas Pertambangan dan Energi maupun Dinas Lingkungan Hidup, akan semakin memperparah keadaan lingkungan di daerah ketika fungsi pengawasan pranata daerah diamputasi dalam perubahan. Adanya kewajiban reklamasi dan pascatambang sudah dari awal disertakan dalam dokumen lingkungan, agar dapat dilakukan monitoring proses hingga berakhirnya kegiatan usaha pertambangan yang akan direklamasi guna memulihkan fungsi lingkungan hidup dan ekosistem di sekitarnya. Selain itu, diperlukan kebijakan penal melalui sarana pidana lingkungan yang efektif dalam ketentuan UU No. 3 Tahun 2020

31 Lihat Putusan Mahkamah Konstitusi Nomor 10/PUU-X/2012, yang diajukan oleh Pemohon Isran Noor, dalam perkara Pengujian Undang-Undang Nomor 4 Tahun 2009 tentang Pertambangan Mineral dan Batubara terhadap Undang-Undang Dasar Negara Republik Indonesia Tahun 1945.

32 Lihat: Putusan Mahkamah Konstitusi Nomor 32/PUU-VIII/2010, diajukan oleh Pemohon WALHI, dkk, dalam perkara permohonan Pengujian Undang-Undang Nomor 4 Tahun 2009 tentang Pertambangan Mineral dan Batubara terhadap Undang-Undang Dasar Negara Republik Indonesia Tahun 1945. 
ketika terjadi suatu kejahatan lingkungan, baik kejahatan lingkungan di bidang pertambangan yang dilakukan oleh pemerintah sendiri dalam bentuk pembiaran untuk tidak ditindak kepada pelaku usaha, maupun pelaku usaha sendiri sebagai pemegang IUP.

Negara wajib menjamin dan melindungi hak-hak konstitusional masyarakat sekitar usaha pertambangan. Hal tersebut dikarenakan setiap saat seseorang dalam kondisi terancam kehilangan kepemilikan tanah dan tempat tinggal akibat berada dalam wilayah pertambangan, korban dari kejahatan lingkungan, perubahan bentang alam, penggusuran, hingga pemidanaan masyarakat sekitar, serta kehilangan hak untuk mendapat perlindungan terhadap harta benda baik yang dikuasai secara individu maupun komunal baik berupa tanah maupun sumbersumber kekayaan alam. Selain itu negara harus memastikan bahwa terdapat suatu hak untuk bertempat tinggal dan bebas dari paksaan berpindah tempat tinggal, dan hak untuk mendapat lingkungan hidup yang baik dan sehat terkait kegiatan usaha pertambangan, sehingga bukan hanya berorientasi pada investasi belaka.

Jaminan pemegang IUP atas kewajiban melaksanakan kaidah teknik pertambangan yang baik menurut penulis harus disertakan pada saat melakukan penyusunan dokumen lingkungan, sehingga sudah dapat terpantau sejak perizinan lingkungan. Selain itu, yang lebih urgen adalah dibutuhkan pemberlakuan sistem pengawasan terpadu di daerah untuk memastikan bahwa kaidah teknik pertambangan yang baik dalam rangka pengelolaan dan pemantauan lingkungan pertambangan, reklamasi dan pascatambang, serta terpenuhinya baku mutu lingkungan, karena pemerintah pusat tidak akan mampu melakukan pengawasan atas sejumlah IUP atau IUPK yang beroperasi pada sejumlah wilayah di Indonesia.

\section{Penutup}

Berdasarkan hasil penelitian dan pembahasan di atas, penelitian ini menyimpulkan pertama, persoalan penyelesaian hak atas tanah untuk kegiatan usaha pertambangan mineral dan batubara berdasarkan UU No. 3 Tahun 2020 terjadi dalam tataran norma dan implementasi. Persoalan dari segi normatif adalah penyelesaiannya dilakukan oleh pemerintah pusat dan pengaturannya ditindaklanjuti dalam bentuk Peraturan Pemerintah. Hal tersebut sangat bias 
sehingga akan mengaburkan fungsi negara sebagai pengatur dan pemberi izin, serta berpotensi melahirkan politik transaksional di pemerintah pusat. Penyelesaian tersebut dilakukan oleh pemerintah melalui mediasi setelah tidak tercapai kesepakatan antara Pemegang IUP atau IUPK dengan pemegang hak atas tanah. Pemerintah yang tidak melakukan evaluasi atas komitmen dalam menjalankan hasil mediasi atau proses mediasi yang tidak aspiratif, maka berpeluang diajukan proses hukum ke pengadilan oleh pihak-pihak yang masih menganggap dirugikan dari hasil mediasi atau kesepakatan antara pemegang IUP atau IUPK.

Kedua, sistem perizinan dan pengawasan atas kebijakan lingkungan berdasarkan UU No. 3 Tahun 2020 belum mendasarkan pada ketentuan UU No. 32 Tahun 2009 sebagai general environmental law. Perizinan dan pengawasan dalam konteks perlindungan dan pengelolaan lingkungan hidup merupakan bagian integral bukan parsial, sehingga sudah seharusnya diperkuat melalui pranata/kelembagaan lingkungan daerah dan dipertegas penaatan atas instrumen lingkungan hidup sebagai fungsi pengendalian. Dibutuhkan pemberlakuan sistem pengawasan terpadu di daerah untuk memastikan bahwa kaidah teknik pertambangan yang baik dalam rangka pengelolaan dan pemantauan lingkungan pertambangan, reklamasi dan pascatambang, serta terpenuhinya baku mutu lingkungan, karena pemerintah pusat tidak akan mampu melakukan pengawasan atas sejumlah IUP atau IUPK yang beroperasi pada sejumlah wilayah di Indonesia.

Penelitian ini merekomendasikan perlunya kajian ulang secara holistik terhadap UU No. 3 Tahun 2020 dari segi norma dan implementasinya, karena berkaitan dengan hak-hak masyarakat tradisional dan masyarakat hukum adat sekitar usaha pertambangan dalam pengelolaan tanahnya, bukan semata berorientasi pada investasi dan perluasan wilayah pertambangan menjadi wilayah hukum pertambangan. Sudah menjadi kewajiban dari Pemegang IUP atau IUPK untuk melakukan penyelesaian permasalahan hak atas tanah yang sesuai dengan penetapan Wilayah Pertambangan oleh pemerintah, dan diperlukan suatu komitmen oleh pelaku usaha pertambangan mineral dan batubara dalam penyelesaian urusan hak atas tanah berdasarkan asas musyawarah mufakat. 
Sistem perizinan dan pengawasan atas kebijakan lingkungan berdasarkan UU No. 3 Tahun 2020 hendaknya menundukkan pada UU No. 32 Tahun 2009 sebagai general environmental law, dengan mempertimbangkan fungsi kelembagaan lingkungan daerah. Diperlukan adanya jaminan atas kewajiban reklamasi dan pascatambang sejak awal yang disertakan dalam dokumen lingkungan, agar mempermudah dilakukan pengawasan dari pelaksanaan hingga berakhirnya kegiatan usaha pertambangan, sehingga dapat memulihkan fungsi lingkungan hidup dan ekosistem di sekitarnya.

\section{Daftar Pustaka}

\section{Buku}

Irianto, Sulistyowati, Hukum Yang Bergerak, Tinjauan Antropologi Hukum, Cet. I, Yayasan Obor Indonesia, Jakarta, 2009.

Nugroho, Wahyu, Ringkasan Disertasi, "Konsep Integrasi Kebijakan Pertambangan Nasional Dengan Masyarakat Hukum Adat dalam Mewujudkan Keadilan Ekologis", Program Doktor Ilmu Hukum Universitas Padjadjaran, Bandung, 2019.

Nurlinda, Ida, Monograf Hukum Agraria Membangun Pluralisme Hukum dalam Kerangka Unifikasi Hukum Agraria, Cet. I, Pusat Studi Hukum Lingkungan dan Penataan Ruang Fakultas Hukum Universitas Padjadjaran \& Logoz Publishing, Bandung, 2014.

Savitri, Myrna dan Moeliono, Tristam, "Bernegara Hukum dan Berbagi Kuasa dalam Urusan Agraria di Indonesia: Sebuah Pengantar", Hukum Agraria dan Masyarakat di Indonesia, Ed. I, HuMa-Van Vollenhoven InstituteKITLV, Jakarta, 2010.

Supramono, Gatot, Hukum Pertambangan Mineral dan Batu Bara di Indonesia, PT Rineka Cipta, Jakarta, 2012.

\section{Jurnal}

Harjanto, Budi, Sukirno, \& Cahyaningtyas, Irma, "Penyelesaian Sengketa Lahan Masyarakat di Konsensi Tambang PT. Mahakam Sumber Jaya Kabupaten Kutai Kertanegara", NOTARIUS, Volume 12 Nomor 1, 2019.

Ismi, Hayatul, "Hak Atas Tanah dalam Pengelolaan Sumber Daya Alam Mineral dan Batubara", Jurnal Ilmu Hukum, Vol. 4 No. 2, Februari-Juli 2014.

Jamin, Mohammad, "Social Conflict Resolution Through Empowerment of Local Wisdoms", Yustisia Jurnal Hukum, Volume 9 Nomor 1, Januari-April 2020.

Nugroho, Wahyu, "Reorientasi Kebijakan Pemerintah Daerah dalam Penerapan Otonomi Daerah di Bidang Pertanahan dan Penataan Ruang", Jurnal Legislasi Indonesia, Vol. 12 No. 2, 2015. 
Redi, Ahmad, "Dinamika Konsepsi Penguasaan Negara atas Sumber Daya Alam", Jurnal Konstitusi, Volume 12, Nomor 2, Juni 2015.

Reki, Natanael Dwi, "Pembatasan Pemilikan dan Penguasaan Hak atas Tanah dalam Perspektif Reforma Agraria", Jurnal Hukum Magnum Opus, Volume I, Nomor 1, Agustus 2018.

Subekti, Rahayu, Karjoko, Lego, dan Astuti, Wida, "Kebijakan Tata Ruang di Kabupaten Kutai Kartanegara (Studi Valorisasi Ruang)", Yustisia Jurnal Hukum, Vol. 2 No.2, Mei - Agustus 2013.

\section{Putusan Mahkamah Konstitusi}

Putusan Mahkamah Konstitusi Perkara Nomor 001-021-022/PUU-I/2003 Pengujian Undang-Undang Nomor 20 Tahun 2002 tentang Ketenagalistrikan terhadap Undang-Undang Dasar Negara Republik Indonesia Tahun 1945.

Putusan Mahkamah Konstitusi Nomor 32/PUU-VIII/2010 atas Pengujian Undang-Undang Nomor 4 Tahun 2009 tentang Pertambangan Mineral dan Batubara terhadap Undang-Undang Dasar Negara Republik Indonesia Tahun 1945.

Putusan Mahkamah Konstitusi Nomor 10/PUU-X/2012, yang diajukan oleh Pemohon Isran Noor, dalam perkara Pengujian Undang-Undang Nomor 4 Tahun 2009 tentang Pertambangan Mineral dan Batubara terhadap Undang-Undang Dasar Negara Republik Indonesia Tahun 1945.

\section{Catatan Akhir Tahun}

Catatan Akhir Tahun 2019 Konsorsium Pembaruan Agraria.

\section{Prolegnas DPR RI 2020}

Program Legislasi Nasional Prioritas tahun 2020: http://www.dpr.go.id/uu/ prolegnas, diakses tanggal 4 Agustus 2020.

\section{Opini Media Online}

Kamarudin dan Della Syahni, Sulitnya Warga Wawonii Pertahankan Lahan dari Perusahaan Tambang, https: / / www.mongabay.co.id/2019/09/19/sulitnya-warga-wawoniipertahankan-lahan-dari-perusahaan-tambang/, diakses pada tanggal 26 Oktober 2020.

Natasya, Nala, "Investasi Tambang dan Perlindungan Hak Milik atas Tanah Rakyat", dalam opininya tanggal 14 Juni 2020 melalui https:/ / detiksultra.com/investasi-tambang-dan-perlindungan-hak-milikatas-tanah-rakyat/, diakses tanggal 27 Agustus 2020.

Nugroho, Wahyu, https://bakaba.co/perampasan-hak-atas-tanah-sebuah-krisiskemanusiaan-dan-ekolog/, diakses pada tanggal 3 Agustus 2020.

Nurkarim, Ikbal, Tuntut Ganti Rugi Lahan, Ratusan Warga Kabupaten Berau Unjuk Rasa di Lokasi Tambang Batu 
Bara, https:/ / kaltim.tribunnews.com/2020/02/10/tuntut-ganti-rugilahan-ratusan-warga-kabupaten-berau-unjuk-rasa-di-lokasi-tambangbatu-bara?page=all, diakses pada tanggal 26 Oktober 2020 .

https:/ / analisis.kontan.co.id/news/menguji-konstitusionalitas-uuminerba, diakses pada tanggal 6 Agustus 2020.

Thea DA, Ady, Jatam: Ada 71 Konflik Pertambangan Periode 2014-2019, https: / / www.hukumonline.com/berita/baca/lt5e14311f6aa5a/jatam-ada-71-konflik-pertambangan-periode-2014-2019/, diakses pada tanggal 26 Oktober 2020.

\section{Peraturan Perundang-undangan}

Undang-Undang Nomor 32 Tahun 2009 tentang Perlindungan dan Pengelolaan Lingkungan Hidup, Lembaran Negara Republik Indonesia Tahun 2009 Nomor 140, Tambahan Lembaran Negara Republik Indonesia Nomor 5059 .

Undang-Undang Republik Indonesia Nomor 7 Tahun 2012 Tentang Penanganan Konflik Sosial, Lembaran Negara Republik Indonesia Tahun 2012 Nomor 116, Tambahan Lembaran Negara Republik Indonesia Nomor 5315.

Undang-Undang Nomor 3 tahun 2020 tentang Perubahan atas Undang-Undang Nomor 4 tahun 2009 tentang Pertambangan Mineral dan Batubara, Lembaran Negara Republik Indonesia Tahun 2020 Nomor 147, Tambahan Lembaran Negara Republik Indonesia Nomor 6525.

Peraturan Menteri Agraria dan Tata Ruang/Kepala Badan Pertanahan Nasional Republik Indonesia Nomor 18 tahun 2019 tentang Tata Cara Penatausahaan Tanah Ulayat Kesatuan Masyarakat Hukum Adat menyatakan: Penatausahaan Tanah Ulayat Kesatuan Masyarakat Hukum Adat, Berita Negara Republik Indonesia No. 1127, 2019 KEMENATR/BPN. Penatausahaan. Tanah Ulayat. Kesatuan Masyarakat Hukum Adat. Tata Cara. Pencabutan. 